The International Journal of Multimedia \& Its Applications (IJMA) Vol.9, No.4/5/6, December 2017

\title{
EXPLORING THE USE OF DigITAL DEVICES AMONG Pupils With LEARNiNg Disabilities
}

\author{
MohdRazimiHusin \\ Department of Human Development, Sultan Idris of Education University, \\ TanjungMalim, Perak, Malaysia
}

\begin{abstract}
The use of digital devices helped pupils memorize, enhance understanding and fully participate in learning. One of the findings is that, during 55\% of the time of the researchers observation, the computers were not used at all. The purpose of this study is to assessing teachers' emphasis, exploring the positive effect of using digital devices on PLD and the use of support software of digital devicesinTnL.This study used a qualitative approach of case studies that involve interviews, observations and analysis of documents of pupils work. The findings showed that teachers always perform audio activities using digital device tools such as computers. These activitieswere particularly relevant with the PLD learning style. The popular support resources used include digital software, mobile phones and youtube.Teachers are encouraged to use digital devices and software due to several effects on PLD such as focusing with fun in learning.
\end{abstract}

\section{KEYWORDS}

Digital Devices, Learning Style \&Pupils with Learning Disabilities

\section{INTRODUCTION}

Every pupil in our country has the same opportunity to receive education regardless of age, gender or race. The National Education Philosophy's aspiration for pupils to be advanced in terms of intellectual, spiritual, physical, emotional and social needs should be realized. Education for all should start as early as possible for children. The effort to produce balanced human beings also begins when children enter the preschool to ensure that every Malaysian can have quality life when they grow up as adults. To realize this expectation, all parties including the government and the private sector should make every effort to provide the best facilities. This desired education also involves pupils with learning disabilities (PLD). Generally the basis of the implementation of Special Education either in Malaysia or international level, emphasizes on physical, emotional, spiritual, and intellectual development so that pupils can get the highest level of education to enable them to get jobs and live independently [1]. Such development requires the competency and efficacy of teachers. The competency and efficacy that teachers possess help students with learning disabilities (LD) acquire the needed learning skills [29].

PLD also have the opportunity to succeed when their potential is polished by teachers through the transformationof education. Teachers should be prepared with the necessary knowledge and skills needed to implement the transformation. The government, private sector and individuals need to provide solid support through various means such as hosting a conference that benefits all parties. The Ministry of Education has been working on adding classes and teachers to accommodate the needs of education to Malaysians starting from preschool. Other educational needs also cannot be excluded, especially information and communication technology (ICT) based learning resources. ICT resources are used by teachers during teaching and learning (TnL) either in the classrooms or in computer labs. In the classrooms, teachers use laptops or display videos on screen through the LCDs whereas pupils are not allowed to bring digital devices to school. Most recently, pupils 
were only allowed to use computers and tablets at school [31]. Other digital devices such as mobile phones are not allowed at all to be used in schools.

\subsection{BACKGROUND RESEARCH}

The study involving learning styles in Malaysia was carried out in Perak on pre-school interactive multimedia software. The interactive multimedia software helps the teacher to create more interactive teaching materials and develop activities that stimulate curiosity [19]. Learning style studies by Dunn and Dunn which identified the learning environment, the learning style and understanding of concepts by pupils in primary schools [11]. The method of the study were experiment in school classrooms in America that did not provide the same classroom environment as in the Malaysia. Dunn and Dunn had developed a learning style table that is appropriate for the local context and can be used by teachers to reflect the differences between pupils. However, this study did not look at the suitability of the environment, but focused on the use of digital devices during teaching and learning $(\mathrm{TnL})$.

\subsection{Problem Statement}

There is no specific model suitable for PLD that allows trained teachers and teachers in primary schools to receive critical exposure with learning style-based approaches. The Teaching and Learning Modules of Iqra and Practical Methods were issued by the Ministry of Education in 2005. These modules do not address the methods, approaches and learning styles that must be applied in the TnL process to PLD. The situation is further complicated when no teachers were trained specifically in Islamic Education for PLD. This weakness made it difficult for teachers in the delivery of knowledge and skills to pupils, and became more complicated when applied with various stimulus of learning styles including environment, emotion, sociology, physiology and psychology [11]. The models and guidance required are models that are closely related to pupils' condition [11]. Therefore, this study included the physiological aspect that is the use of appropriate teaching aids in accordance with the pupils' learning styles.

The previous study found that teachers were less familiar with the TnL operations through pupils' learning styles [34]. They simply teach and attract PLD to learn without knowing the true concepts of learning styles. The study shows that the pupils' performance is better when teaching and learning takes into account the appropriate learning styles as compared to pupils who were taught without taking into consideration their learning styles [18]. The Malaysian Education Blueprint 2013-2025 and Malaysian Teacher Standards or Standard Guru Malaysia [23] document emphasize learning styles to achieve effective learning. The study [16] found that the use of rhythm, songs and digital story telling helped pupils memorize, enhance understanding and fully participate in learning with fun. Their studies pointed out the effectiveness of songs even though the tools used for such activities involved digital devices. One of the findings is that, during $55 \%$ of the time of the researchers' observation, computers were not used at all [6]. Hence, more specific and comprehensive studies need to be carried out not only by focusing on the use of songs in PLD styles of learning but the use of digital devices to enable further actions to be taken in producing the appropriate software or software innovations as $\mathrm{TnL}$ materials.

\subsection{RESEARCH OBJECTIVE}

The study was conducted to:

i) Assess teachers' emphasis and the positive effects of using digital devices on PLD.

ii) Explore the use of supporting software for digital devices in TnL.

\subsection{RESEARCH QUESTION}

In general, the researcher posed the following questions: 
The International Journal of Multimedia \& Its Applications (IJMA) Vol.9, No.4/5/6, December 2017

i) How far has the use of digital devices been emphasized by teachers and what are their positive effects on PLD?

ii) What are the other supporting resources for digital devices used in TnL?

\subsection{IMPORTANCE OF THE STUDY}

The main purpose of this study is to contribute significantly to PLD, especially through learning practices based on physiological element of learning styles. In addition, this study also benefits teachers when the learning practices are based on appropriate learning stimulus through the learning guide produced. The main emphasis of this study is how to produce the right resources through the use of digital devices. This contribution is obtained through the appropriate ideas shared among ICT experts.

\section{Limitation Of The Study}

This study is based on the Dunn and Dunn Learning Styles Model which is related to the way pupils obtain information. This study focuses on the physiological element in the learning styles that is the use of digital devices which is one of the PLD learning styles. This research focuses only on pupils in the Special Education classes of a primary school.

The pupils selected as participants were pupils who were enrolled in the Special Education Integration Program in the category of minimal intellectual disabilities or known as High Level Capability Learning pupils (HLPLD). The six pupils selected as participants had similar characteristics in their functionality. The participants' age ranged from 10 to 12 years old. Teachers and parents also participated in this study.

\section{Literature REVIEW}

Parents, teachers and others are encouraged to share information, monitor development and build profiles to explain the difficulties faced by children and determine positive ways to help them. One of the earliest signs of PLD is that children cannot crawl at all before they start to walk. Normally children are capable of crawling before walking. PLD may have speech problems and their language is not understood by others. Their speech must be supported by their body language before being understood by parents. PLD are found to have been left behind in reading which can be two or three years backwards as compared to their peers. In other words, they are categorized as pupils who have unequal capacities when compared with other pupils. There are no specific learning styles to tailor to their learning except a teaching strategy that takes into account the needs of each PLD. Teachers need to convince pupils about their strengths and abilities in many ways that can help them overcome difficulties such as getting responses through drawing or flow chart rather than through conversations or writing [34]. A study was found that PLD were very interested in gadgets and they could intuitively use the gadgets [34]. They not only used gadgets for entertainment, but also for accessing learning information at home. However, the use of gadgets is not very popular in schools due to factors such as cost and school regulations [31]. The review [33] shows that there are three main characteristics of learning styles that exist in PLD which are related to computer usage. In the emotional stimulus of the element of perseverance, all pupils can learn for 10 minutes through the song track using a laptop without feeling bored. While in the sociology stimulus they love to learn side by side with teachers and adults especially when viewing songs on the screen of the computer. For physiological stimuli, in the element of perception they learn well through touching the materials brought by the teacher and also their experience in singing according to the song aired on the laptop. Knowing pupils' learning styles is useful for determining learning situations, tools and teaching approaches. A suggested [5] that teachers should present information in various forms and provide different learning experiences such as using videos, audio-visual, audio tapes, songs, debates and group work. 
The International Journal of Multimedia \& Its Applications (IJMA) Vol.9, No.4/5/6, December 2017

Teachers should provide different learning experiences as proved by the study results which supported the hypothesis that people have cognitive differences in learning [27].

\section{Methodology}

This study used a qualitative approach of case study that involved interviews, observations and analysis of documents of pupils' work. Interviews, observations and data were collected using either interview protocols, observation forms, audit trail notes, video recorders, or pupils' work. Triangulation was conducted by the researcher to obtain accurate and saturated information. Triangulation was made as one of the case study methods, namely observation, interview and analysis of documents of pupils' work. The PLD learning analysis was carried out using Nvivo software that determined the findings of this study.

\subsection{SAMPLING Of THESTUdY}

The participants of this study consisted of six Special Education pupils in two selected schools in Perak, four teachers and six parents. The selection of the research participants was based on purposive sampling that met the specific criteria determined by the researcher. The specific criteria were based on research issues to be studied in depth to ensure the right choice of participants [46] \& [8].

\subsection{Research Procedure}

In short, the methodology suitable for this study was the qualitative approach of case study. In the early stage of this study, the participants of the study were chosen based on the criteria determined. At the same time, the interview protocols, and observation forms were prepared as well as audit trail notes, video recorders before the researcher was ready to conduct the fieldwork. Those interview protocols and observation forms were validated first by experts.

During the interviews and observations conducted, the pupils' work were also studied to compare with the data of the interviews and observations. The data were analyzed after each fieldwork. The process was carried out continuously until the data were saturated. At the end, the researcher made the conclusion to all data collected based on saturated themes. All those data were analyzed using Nvivo software that determined the findings of this study.

\subsection{Data Collection Tool}

The main method in this study was interview. The interviews conducted with participants for this study required an appropriate protocols. The protocols of this study contained the authorized and verified components [40]. The data were obtained using data collection tools such as interview protocols and observation forms. The interviews and observations were analyzed qualitatively. Qualitative analysis using Nvivo software were carried out to get the themes to answer the research questions.

\subsection{VAlidity Of The STUdy}

For the purpose of fulfilling the validity of constructs, evidences were obtained from various sources of interviews, direct observations and video recordings. All the data collection methods were analyzed to ensure that there was a string of strong evidences. In order to obtain the internal validity of this research, the findings were verified by field experts which included Special Education, ICT and Psychology. Meanwhile for the external validity, the researcher had to compare the findings with the existing theories, making the analysis of the similarities and the differences between the findings of this study and the second party to enable the study findings to be assessed to what extent it can work and function in a second-party situation [48]. 
The International Journal of Multimedia \& Its Applications (IJMA) Vol.9, No.4/5/6, December 2017

\section{FindingS}

The findings focused on teachers' emphasis and the impacts of the use of digital devices to PLD learning and supporting resources used during $\mathrm{TnL}$ with digital devices.

\subsection{Teachers' Emphasis and Impacts of the Use of Digital Devices to PLDLearning}

In In the physiological stimulus, audio is one of PLD's learning styles. Based on observations and interviews, teachers of Islamic Education always conducted audio activities using digital devices such as computers. Audio activities involved nasyid and stories. These activities were particularly relevant with the PLD learning styles as reported below. However, these activities involved the visual process as pupils were more focused on seeing movements on nasyid and acting in the stories.

Based on the observations, it was found that the teachers had asked pupils to listen to a recitation using laptop as follows;

\section{(HLPLD: SF / AUDIO / COMPUTER): "Azam read after listening to the recitation on the teacher's laptop."}

Additionally, teachers always showed stories on the computer screen that used the audio and visual teaching technique. Azam listened and watched the story through a teacher's laptop. When asked about what he heard and watched, he replied;

\section{(HLPLD: SF / AUDIO / KOMPUTER / STORY): "That day, teacher showed the story of the Prophet Joseph."}

The teacher used the audio tool together with visual equipment to facilitate the delivery of the lesson. The audio tool used such as laptops could attract PLD to receive the information and skills delivered. Through the perceptions element in this study, videos shown using a laptop screen could prevent PLD from becoming sleepy. The processing of information by PLD was more effective as the PLD could imitate what they watched. However, after a break at eleven o'clock in the morning, the PLD were less active and often unable to concentrate. The ideal way to keep them focused was to display videos related to the topics taught otherwise the pupils would be bored if the teachers were to use the explanation teaching method. This is an appropriate way of addressing boredom as Hazim stated;

$$
\text { (HLPLD: SF / PERCEPTION / VISUAL / SCRIPT): "..just bored .. upload video." }
$$

PLD had difficulty to remember the story based on the text read as compared to watching the story using a laptop. They found it difficult to receive information through reading only. The story was easily understood through the video shown as they were able to relate what they watched in the following transcript;

\section{(HLPLD: SF / PERCEPTION / VISUAL / SCRIPT): "She likes to hear stories. I agree ..because through the story, it is very easy to remember, for example, when I shared the story of the prophet with Zulaikha, I showed the video of the story, she could remember better." the story, .. when I read the text, it was hard for her to remember."}

Video clips were shown to enable PLD perform other activities such as tasmik (teacher listening to the pupils' reading) carefully and cautiously. They would be eager to read and were careful not to make mistakes to ensure that their teacher would show them videos after that. They also had the same habits at home, watching television and entertaining games on laptops. Other than the visual features, the learning style of audio features could also improve the quality of PLD 
The International Journal of Multimedia \& Its Applications (IJMA) Vol.9, No.4/5/6, December 2017

learning. They loved listening to nasyid (religious songs) that were shown through video clips like ' $\mathrm{Aa}$ ' 'Ba' ' $\mathrm{Ta}$ '. They would sing the song as follows;

(HLPLD: SF / PERCEPTION / AUDIO / SONGS): "Teacher showed a video clip song of ' $\mathrm{A} a$ ' ' $\mathrm{Ba}$ ' ' $\mathrm{Ta}$ '. Hazim joined in singing the song loudly."

In short, PLD did not have the tendency to read texts solely. They were more inclined to listen and watch before they could process and store new and challenging information in their minds. Videos shown on the computer screen not only included the visual element, but also included audio whereby they could sing together. Finally, they could easily remember the text after watching and listening to videos in a lesson. PLD also loved songs. Learning through nasyid was their learning style because they loved to store information in their minds through that way. Hazim and his friends stated that they loved nasyid. Nasyid was also watched and heard through computer video clips. They were engaged in singing along with the video clips. They only watched the first time a video clip was played and could sing when the video clip was played for the second time. Azam during an observation was found to be as follows;

(HLPLD: SF / PERCEPTION / AUDIO / SONG): "Teacher played a nasyid song. Azam watched the song seriously and sat still. Then the teacher repeated the song, and Azam could sing the song."

\subsection{Supporting Resources Used During TnLWith Digital Devices}

The source materials or learning resources are everything that support the learning process. Teaching and learning aids that can be used to assist teachers in the teaching process are also categorized as source materials. Source materials can either be in the form of equipment, hardware or media software material, data, facts, ideas, people and so on. Popular supporting resources used include digital software, mobile phones and YouTube.

\subsubsection{Digital Software}

CD and VCD software that contains the lyrics of the appropriate song are important source of learning for these pupils. They could remember the lyrics of the songs well and as a result could understand the information delivered by their teacher. The nasyid song software was the primary source used by teachers in the use of ICT in the classroom. The message of the lyrics of the songs were then further enhanced by the teacher through class discussions. PLD were seen to have fun and enjoyed this kind of learning. Therefore, lyrics of songs were very meaningful in their TnL because the use of rhythm and songs could assist them to store information easily in their minds like the following statements;

(HLPLD / SL / SONG / MUSIC): "When the teacher showed the video of the 'Alif' ' $b a$ ' ' $a$ ' song through a computer, Azam loved the song.He could remember the song and sang along to the beat."

Teachers also utilized lots of Arabic genre software as resources in the classroom. The software contains songs about learning in many core subjects as shown in the following statement made by a pupil;

$$
\begin{aligned}
& \text { (HLPLD / SL / SONG / MUSIC): "..CD songs of 'alif' ' } b a \text { ' 'ta'.. song of ablution } \\
& \text { and prayer .." }
\end{aligned}
$$

In addition, other music software used by teachers as a learning resource could attract pupils' attention. The use of music was a physiological stimulus combining audio elements and multisensory elements. Teachers who conducted TnL to PLD by playing audio songs were able to 
The International Journal of Multimedia \& Its Applications (IJMA) Vol.9, No.4/5/6, December 2017

accommodate the pupils' learning style as pupils were happy to receive the information as they enjoyed the rhythm of the songs based on Mrs. Lina's account;

(HLPLD: SL / MUSIC): "I played a song because of he loved the song... singing the song enabled him to remember the information easily.."

Mahfudz was able to answer questions posed by teachers verbally regarding the content of the music videos shown in class during the discussion session. PLD were more focused on learning when video clips were used. It was easier for PLD to remember the information contained in the song as Mrs. Lina said;

(HLPLD: SL / NASYID / MUSIC): "That's exactly what he likes because if he's singing it's easy for him to remember .. when singing, he followed the rhythm of the song that I had shown in the video clips because that's what he liked .. a lot of solat songs and ablution because there are a lot of software available. It's a lot of fun too."

\subsubsection{YouTube}

Some Some pupils used their personal computers at home to find learning materials through YouTube. Mahfuz, who liked to sing the song about the Names of the Prophet, listened to the song on his own outside the school as he said;

(PLD: SF / PERCEPTION / AUDIO / MUSIC): "..looked in the book .. in YouTube I would find the song on my own...".

\subsubsection{Cell phone}

Hazim searched for learning materials using smart phones at home. Hazim was very skilled at using smart phones and was able to explore on his own to look for information with the gadget as confirmed by his mother;

(PLD: SF / PERSEPSI / TEL): "...he is very good at using mobile phones at home even though he's a slow learner. Information sought for self-study was obtained easily."

In conclusion, various resources have been used by teachers in helping to increase information obtained and engage pupils in the classroom activities. The experience of using lyrics of songs, singing or nasyid enabled pupils to have fun as well as facilitate the process of memorizing the content delivered. Another popular source material used by teachers and which was found to successfully enhance PLD skills was computer software. Meanwhile YouTube and cell phones were also used by pupils to access materials at home.

\section{RESEARCH DISCUSSION}

The physiology stimulants contain four elements namely perception, intake, time of energy levels and mobility. This study found some other stimulus besides the four physiology stimulus which include multi-senses stimulus, song stimulus, Qiraah stimulus and Tikrar stimulus. The perceptual element involves the characteristics of individuals who like to study with objects, hands on experiences or on abstract matters. The intake element involves the characteristics of individuals who like or otherwise dislike eating and drinking while studying. Time of energy levels element involves the characteristics of individuals who like to study at a certain time or otherwise at any time. The mobility element involves the characteristics of individuals who like or do not like to move while studying. In this study, PLD were found to have a perceptual element that involves the characteristics of individuals who love learning with objects or hands on experiences. PLD liked to study by listening to songs as shown when teachers played the nasyid videos. This 
method involves a multi-senses stimulus learning style. They could answer verbal questions by teachers about the content of the nasyid videos in class discussions. The quantitative results obtained indicated that most Malaysian students are auditory learners [14]. Individuals with high auditory perceptions could learn effectively if exposed to specific audio devices such as radio, cassette and video. This category of pupils would remember the information they hear, be able to focus on a longer duration and could describe the sounds they hear [11]. In addition, the skills of orality that is oral delivery of teachers to pupils and the traditional way of delivery of knowledge to pupils should be suitable for specific subjects such as Islamic Education [17].

Individuals with visual perceptions are more likely to respond and understand information and skills with learning aid materials such as videos, slides, charts, televisions, graphs, diagrams and illustrations. Dunn and Dunn [11] explain visual perceptions involving focus on paragraph reading and page readings. According to a study [28], in explaining the learning style theory, teachers must know that pupils learn in a unique way, usually in auditory, visual, and kinaesthetic modes. To improve pupils' performance, firstly all educators need to identify the pupils' learning styles and then match the way they teach for each style. Therefore, this study has found that the acceptance of pupils will be more robust and effective through a combination of audio and visual perceptions. In addition to the elements mentioned previously, there are also pupils who like to learn by listening to nasyid songs through nasyid videos shown. PLD would sing together the audio they heard and could express the nasyid video content in class discussions. A study [36] stated that singing elements could help pupils by enhancing their understanding of a concept. While another study [16] found that students engaged in the digital story telling were very high motivation and fully involved in learning. This involves auditory perception as individuals with high auditory perceptions can learn effectively if exposed to specialized audio devices such as radio, cassette and video. This pupil will remember the information being heard, able to pay attention and can describe the sounds heard [11].

Besides qiraah, tikrar is also a stimulus of the new learning style element. The results of this study and some other studies showed that pupils could receive and master the skills delivered well through this learning style. This learning style is also hardly discussed and studied. Pupils will quickly get bored if the style of repetition learning is not done through various techniques. A good example of this technique is when a teacher starts the sample reading and repeats the reading more than three times and does not let the pupils read it first for three times. The use of other aids will increase pupils' interest such as audio and other audio-visual tools. This learning style of repetition is widely used to ensure pupils' mastery in the area of worship, recitation of the Quran and jawi (a special form of writing). The study [2] found that repetition helped pupils to write jawi letters using the various method. This method started with the description by the teacher in introducing the letters to be taught. Then letters were sorted by categories before repetition on the whiteboard was done using the kit boxes. Other findings showed that the multisenses explication activities are another language learning mode, especially on the mastery of suitable words based on the LD children's mind. The interview sessions and the observations showed the improvised language learning game managed to attract the attention of the students and triggered the feelings of pleasure of the LD children in learning Malay language which they felt was difficult to master previously [42].

As stated above, pupils will quickly get bored if the style of repetition learning is not done through various techniques.But, since PLD has a high fortitude, mastery learning can be implemented to them. The 30 minute period is suitable for various activities for this PLD. The high fortitude shown by PLD in particular enable the teacher to take opportunity to enhance students' knowledge and skills of the Quran and Solat. Based on the study [30], mastery learning should be carried out with the help of teaching videos and better if the video is in the form of games inserted with information and learning concepts to be achieved. 
The International Journal of Multimedia \& Its Applications (IJMA) Vol.9, No.4/5/6, December 2017

\section{Conclusion}

The findings of this study have resulted in several effects on the use of digital devices among PLD such as assisting them to be more focus and comprehend in the lesson. Besides that, they felt fun through various techniques of teachers' instructions. Learning became more effective and attractive when teacher using multi-sensory devices. The suitable video shows were chosen by teacher in TnL to PLD played an important role in their receiving new information and skills taught. They would be very easy to follow something they watched and heard simultaneously like they could sing the song that they experienced watching video shows with their friends.Therefore, teachers are encouraged to choose the appropriate supporting materials in the implementation of TnL using digital devices and softwareas the study findings. Teachers interest in play-based teaching using technology to attract pupils and activate them in kinaesthetic way. A study [12]found thatconcept of play and technology among childhood wouldboost pupils understanding towards the lesson. However, according to the study there are problems with technology and digital media with play-based learning. Methods of using digital devices wisely in the classroom need to be discussed more deeply by taking into account the views of educational leaders to ensure the learning environment can be harmoniously implemented. To ensure it works, there are some evaluations in various aspects before fully implementing in the school. As an Islamic state the syariah boundaries should be taken into account in Malaysia regarding this issue.

Audio activities using digital device tools such as listening lesson using computersis one of PLD's learning styles. The audio activities involve singing and acting on stories of the song lyrics following by discussion of the stories of the singing afterwards. The discussion should engage with open-ended questions based on lyric texts of the song [9]. The main source material is either something in the form such as hardware or media software material. The most popular support resources used include digital software, mobile phones, and YouTube. Lesson is more effective by using the digital devices in this era. The suitable devices are tablets and laptops, whereas mobile phones would make pupils lame and cause bad effect in classrooms. Pupils could fulfill interactive learning by using the suitable digital devices as stated earlier. Most importantly, the authority has to design rules and guidelines due to bad circumstances coming by using the devices. They are proposed to use within two hours duration only in any respective subject matter [31].

This study is a qualitative study with multiple case study methods aimed to see the excellence characteristics of PLD either in primary or secondary schools. Therefore, in order to strengthen the success achieved in the findings of the study, the researcher suggested that the following study was a qualitative comparison study between PLD and other pupils in various fields. This comparative study recommends that the differences and weaknesses inherent in PLD can be observed, presented, and listed to further actions on formation and implementation of the curriculum and methods of teaching to PLD. This formation and implementation are not only in field of digital devices but also in another technique to deal with them. The next study should be emphasized on the classroom environment-related practices. Therefore, it is proposed that subsequent studies are based on the findings of this study to support this finding as well as for the use of other student groups. Other researchers can build learning style inventories that emphasize on standardization of content and specific learning for specific subjects.

It is clear that all aspects of this study are important to PLD as well as teachers. Hence, the researcher suggests that there should be a new study to develop a more comprehensive and integrated curriculum strategy based on the findings. The researcher also suggests that future researchers will study specifically about the influence of teachers and parents in determining student learning styles because surrounding influences are very important. Similarly, the characteristics of PLD learning styles can also be compared to students who are in an inclusive class. Finally, it is recommended that a study on the characteristics of PLD learning styles by 
The International Journal of Multimedia \& Its Applications (IJMA) Vol.9, No.4/5/6, December 2017

focusing on certain stimulus in-depth. In order to facilitate future researchers, interview protocols that are certified by experts used in this research could be guided in getting in-depth information to build a strong curriculum and learning strategy to implement for not only to PLD but also to other students. The future researcher are also suggested to produce appropriate resources through the use of digital devices. This particular resource of devices will be more establish if they are produced through the contribution of the information technology (IT) experts. Instructors need more study on digital devices element of learning styles not only for students with disability but to all students regardless their age and background because of the individual uniqueness that differs from one to another person.

\section{REFERENCE}

[1] Abdullah Yusoff., Shukri Ismail., NikAzharNikAb Rahman.,\&AzhariMuhamood., (2011) "PengurusankurikulumPendidikanKhasMasalahPembelajaran:

Satukajianawaldankeperluaninovasi",InProceeding of International Conference on Early Childhood and Special Education 2011,Pulau Pinang, UniversitiSains Malaysia.

[2] Abdul Halim Tamuri., (2011) "KreativitidaninovasidalampengajarandanpembelajaranPendidikan Islam di Malaysia”,In KonvensyenKebangsaanPendidikan Islam 2011,Kuala Lumpur, University of Malaya.

[3] Ahmad Mohd. Salleh., (2004) "Falsafah, SejarahdanKaedahPengajarandanPembelajaran",Selangor, PenerbitFajarBaktiSdn.Bhd.

[4] Alias, N., \&Siraj, S., (2012) "Design and development of physics module based on learning style and appropriate technology by employing Isman instructional design model”, Turkish Online Journal of Educational Technology, Vol. 11, No. 4, pp84-93.

[5] Alireza, H., (2009) "Learning and cognitive styles as effective factors in learning english for EFL pupils", Journalof Learning, Vol. 16, No. 6, pp144 - 194.

[6] Andersson, A., Wiklund, M., \&Hatakka, M., (2016) "Emerging collaborative and cooperative practices in 1:1 schools", Technology, Pedagogy and Education, Vol. 25, No. 4, pp413-430.

[7] AzmanAb Rahman., NorakyaireeMohdRaus., Hussein Azeemi Abdullah Thaidi.,\&Mohammad NaqibHamdan., (2014) FiqhJenayah Orang KelainanUpaya,Negeri Sembilan, UniversitiSains Islam Malaysia.

[8] Burns, R. B., (2000)Introduction to Research Methods, London, SAGE Publications.

[9] Caviglia, F., \&Delfino, M., (2016) "Foundational skills and dispositions for learning: an experience with information problem solving on the web", Technology, Pedagogy and Education, Vol. 25, No. 8, pp487-512.

[10] Cassidy, S., (2004) "Learning styles: An overview of theories, models, and measures", Journal of Educational Psychology, Vol. 24, No. 4, pp419-444.

[11] Dunn, R.,\& Dunn, K., (1992) Teaching Elementary Pupils Through Their Individual Learning Styles: Practical Approaches for Grades 3-6, United States of America, Allyn and Bacon.

[12] Edwards, S., (2016) "New concepts of play and the problem of technology, digital media and popularculture integration with play-based learning in early childhood education", Technology, Pedagogy and Education, Vol. 25, No. 9, pp513-532.

[13] Ehrman, M.,\& Leaver, B., (2003) "Cognitive styles in the service of language learning”,System, Vol. 31, No.3, pp393-416.

[14] Foroutan, M., Nooreen, N., Gani, S.H., \&Baki, R., (2013) "The relationship between language learning autonomy extent andlearning styles in Malaysian context”, World Applied Sciences Journal, Vol. 24, No. 3, pp395-402.

[15] Goh Min Lee., (2011) "Penggunaankaedahnyanyiantelahdigunakandalampenguasaansifirdarab 6 hingga 8 muridtahun tiga", Jurnal action research, Vol. 1, No. 2, pp20-23. 
The International Journal of Multimedia \& Its Applications (IJMA) Vol.9, No.4/5/6, December 2017

[16] Hannele, Niemi.,\&Jari, Multisilta., (2016) "Digital storytelling promoting twenty-first century skills and student engagement”, Technology, Pedagogy and Education, Vol. 25, No. 6, pp451-468.

[17] Hardaker, G., \& Sabki, A.A., (2012) “An insight into Islamic Pedagogy at the University of alQarawiyyin”,Multicultural Education and Technology Journal, Vol. 6, No. 2, pp106-110.

[18] Hwang, G., Sung, H.Y., Hung, C.M., \& Huang, I., (2013) “A learning style perspective to investigate the necessity of developing adaptive learning systems",Educational Technology and Society, Vo. 16, No. 2, pp188-197.

[19] Isotani, S., \& De Oliveira Brandao, L., (2013) "The roles of teachers and students when facing an interactive geometry software: Igeom", Bolema-Mathematics Education Bulletin, Vol. 27, No. 45, pp165-192.

[20] JabatanPelajaran Perak., (2013)Rumusan PPKI Perak 2013,Unit PendidikanKhas JPN Perak.

[21] KementerianPelajaran Malaysia., (2005a) ModulPengajarandanPembelajaranAmaliSolat Program jQAF di Pendidikan KhasMasalahPembelajara,Kuala Lumpur, BahagianPendidikanKhas.

[22] KementerianPelajaran Malaysia., (2005b)ModulPengajarandanPembelajaranKaedahIqra' Program jQAF di Pendidikan KhasMasalahPembelajaran, Kuala Lumpur, BahagianPendidikanKhas.

[23] KementerianPelajaran Malaysia., BukuPanduanInstrumenPenentuanPenempatanPendidikanKhasBermasalahPembelajaran (I.P.P.),Selangor, JabatanPendidikanKhas.

[24] KementerianPelajaran Malaysia., (2012) BukuteksPendidikan Islam Tahunsatu, duadantigauntukmuridPendidikanKhasMasalahPembelajaran,BahagianBukuTeks.

[25] KementerianPelajaran Malaysia., (2012) LaporanAwalPelan Pembangunan Pendidikan 2013-2025.

[26] KementerianPendidikan Malaysia., (2004) PendidikanKhasMasalahPembelajaran, Modul 2/3 Unit 5/6: KaedahpengajarankhasSains,Kuala Lumpur, BahagianPendidikan Guru.

[27] Laguzzi, J., Bernardi, S., Araujo, A.M., Ventura, A.C., \& Vigliano, F.A., (2013) "Learning-styles of students of veterinary medicine in the National University of Rosario, Argentina", RevistaVeterinaria, Vol. 24, No. 2, pp151-156.

[28] La Lopa, J. M., (2013) “The difference between bigfoot and learning styles: There may be better evidence to support the existence of bigfoot",Journal of Culinary Science \& Technology, Vol 11, No. 4, pp356-376.

[29] Levi, U., Einav, M., Raskind, I., Ziv, O.,\& Margalit, M., (2013) "Helping students with LD to succeed: The role of teachers' hope, sense of coherence and specific self-efficacy", European Journal of Special Needs Education, Vol. 28, No 4, pp427-439.

[30] Lin Liu, E. Z. F., Chen, Y. L., Liou, P. Y., Chang, M., Wu C. H.,\& Yuan, S. M, C., (2013) "Gamebased remedial instruction in mastery learning for upper-primary school pupils,Educational Technology and Society, Vol. 16, No. 2, pp271-281.

[31] Mahdzir Khalid., (2017, Ogos 9),Utusan Malaysia, 4, BawaPeranti Digital keSekolah.

[32] ajda, S.,\&Helena, C., (2010) "Learning habits of pupils with special needs in short-term vocational education programs, Journal of Educational Studies, Vol. 36, No. 4, pp415.

[33] MohdRazimiHusin., Abd. Aziz Shukor.,\& Ahmad JaziminJusoh., (2011) "MenilaigayapembelajaranmuridbermasalahpembelajarandalammatapelajaranPendidikan Islam dan jQAF”,InProceedingsofInternational Conference and ExhibitionOn Research in Islamic and Arabic Language Education 2011,Langkawi, Hotel Awana Porto Malai.

[34] MohdRazimiHusin., MohamadYusriBakir., Abd. Aziz Shukor.,\& Ahmad JaziminJusoh., (2016) Kesanpenggunaanlaguterhadappenerimaanmaklumatmuridbermasalahpembelajaranberkemampuantah aptinggi: Satukajiankes", JurnalPenyelidikanTempawan, Vol. 33, No. 7, pp63-79.

[35] MohdZuriGhani.,\&AznanChe Ahmad., (2011) PengantarPendidikanKhas,Pulau Pinang, PenerbitUniversitiSains Malaysia. 
The International Journal of Multimedia \& Its Applications (IJMA) Vol.9, No.4/5/6, December 2017

[36] Muhammad Hanif AbLatiff.,\&Samsiah Hassan., (2013) "Penerapanelemenmuzikdannyanyiandalamkonseppenambahanpecahannomborbercampurdenganpeny ebutberbeza”,JurnalKajianTindakan, Selangor, Vol. 1, No. 2, pp8-10.

[37] Nawi, MohdAliffMohd., Sulaiman, Adibah., Jamsari, EzadAzraai., Umar, Azizi., \&Hamzah, Mohd Isa., (2012) "The impact of globalization on current Islamic Education", Australian Journal of Basic and Applied Sciences, Vol. 6, No. 8, pp74-78.

[38] Norliza Hussin., Mohamad Sattar Rasul.,\&RoseamnahAbd. Rauf., (2013) "Penggunaanlaman web sebagaitransformasi dalampenga jarandanpembelajaran PendidikanIslam”, The Online Journal of Islamic Education, Vol. 1, No. 2, pp58-73.

[39] Nor WahidahHasim., (2011) "Kaedahnyanyiandalampembelajarantajukjenisjenismakanan,JurnalKajianTindakan, Selangor, Vol. 1, No, 3, pp11-13.

[40] Othman Lebar., (2009) PenyelidikanKualitatif, Pengenalan kepadaTeoridanMetod,TanjongMalim, UniversitiPendidikan Sultan Idris.

[41] Roesler, R.A., (2017) "Independence pending: Teacher behaviors preceding learner problem solving", Journal of Research in Music Education, Vol. 64, No. 4, pp454-473.

[42] Subramaniam, V., Mallan, V. K., \& Mat, N.H.C., (2013) "Multi-senses explication activities module for dyslexic children in Malaysia”, Asian Social Science, Vol. 9, No. 7, pp241-267.

[43] Standard Guru Malaysia., (2009) BahagianPendidikan Guru, KementerianPelajaran Malaysia. Putrajaya.

[44 Sze, S., (2009) "Learning style and the special needs child", Journal of Instructional Psychology, Vol. 36, No. 4, pp360-362.

[45] Yin, R.K., (1994) Case Study Research: Design and Methods,Newbury Park, CA: Sage.

[46] Yin, R.K., (2003a)Applications of Case Study Research (2nded.), Thousand Oaks, California, SAGE Publications.

[47] Yin, R.K., (2003b) Case Study Research: Design and methods (3rd ed.),Newbury Park, CA: Sage.

[48] Yin, R.K., (2009) Case Study Research: Design and Methods (Fourth Edition ed.), Los Angeles, SAGE Publications.

[49] ZainulIshak., (2006)PanduanKesihatandanKeselamatanKanak-kanak,Selangor, Loh Print.

[50] Zhang, L.,\&Sternberg, R. J., (2005) “A threefold model of intellectual styles”, Journal of Educational Psychology, Vol. 17, No. 1, pp10.

\section{AUTHOR}

MohdRazimiHusin is a Senior Lecturer of the Faculty of Human Development in Sultan Idris Education University. He has twenty years of experience in the educational field and has taught in schools as well as a college before becoming a Senior Lecturer at the Sultan Idris Education University in 2017.

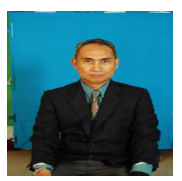

